\title{
AQUACULTURE OF RUSSIAN STURGEON IN URUGUAY: DECREASE OF THE INNATE DEFENSES IN SUMMER AND ITS ASSOCIATION WITH HIGH TEMPERATURES
}

\author{
Mauricio Castellano ${ }^{1 *}$, Valeria Silva-Álvarez ${ }^{{ }^{*}}$, Elena Fernández ${ }^{2}$, Verónica Mauris ${ }^{3}$, Daniel \\ Conijeski ${ }^{2}$, Andrea Villarino ${ }^{1}$, Ana M. Ferreira ${ }^{1 \S}$ \\ ${ }^{1}$ Facultad de Ciencias, Universidad de la República, Iguá 4225, Montevideo, Uruguay. \\ ${ }^{2}$ Black River Caviar, Río Negro, Uruguay. \\ ${ }^{3}$ Biotech-Alltech, Dr. Alfredo García Morales 1155, Montevideo, Uruguay.
}

\begin{abstract}
Sturgeons (family Acipenseridae) are fish species of high ecological and economic value. Unfortunately, sturgeon species are highly endangered; overfishing and pollution have led to a drastic decline of natural reserves. Aquaculture is of decisive importance for the conservation and restoration of sturgeon populations, representing also an activity with valuable socio-economic impact. Acipenser gueldensteadtii (Russian sturgeon) is one of the most cultured sturgeon specie worldwide. In Uruguay, sturgeon farming has been successful, but a high susceptibility to bacterial infection has been observed during summer. We studied the health status of Russian sturgeons, cultured during winter and summer seasons in an Uruguayan farm, by analyzing the activity of some innate immune components, including serum ceruloplasmin $(\mathrm{Cp})$, the alternative complement pathway (ACP) and lysozyme. Adult females exhibited a low serum level of Cp and $\mathrm{ACP}$, and a slight increase of lysozyme level during summer. Since $\mathrm{Cp}$ and ACP activities depend strongly on liver synthesis, we explored whether their alterations were linked to a chronic stress response. Serum protein levels were significantly lower in adult sturgeons during summer, but no significant differences were observed in cortisol. Therefore, a chronic stress response might have altered liver metabolism, interfering with the synthesis of constitutive proteins, including $\mathrm{Cp}$ and ACP components. Examination of the contribution of temperature changes to the observed effects was carried out by analyzing the same indicators in young sturgeons cultured at $18^{\circ} \mathrm{C}$ or $24^{\circ} \mathrm{C}$ during 37 days. In addition, the effect of oral administration of a nutritional supplement containing $\mathrm{Se}, \mathrm{Zn}$ and a yeast-derived immunostimulator (Biopack, Alltech) was analyzed. Exposure to $24^{\circ} \mathrm{C}$ caused a high mortality and a significant decrease in fish growth and serum protein levels, but not changes in cortisol. Cp and ACP activities were significantly diminished at $24^{0} \mathrm{C}$. Results resemble those obtained for sturgeon reared in summer. Biopack administration enhanced fish growth, $\mathrm{Cp}$, and ACP activities in fishes cultured at $18^{\circ} \mathrm{C}$, although failed to reverse the detrimental effects observed at $24^{\circ} \mathrm{C}$. In contrast, Biopack seems to revert the modest increase in lysozyme activity found at $24^{\circ} \mathrm{C}$. Overall, the higher susceptibility of sturgeons to bacterial infections may be caused by the usual temperatures reported during the Uruguayan summer, which would lead to decrease innate defenses as $\mathrm{Cp}$ and ACP. Biopack supplementation may benefit sturgeon health status, but further studies are needed to determine if it could prevent defense deficiencies provoked by high temperatures.
\end{abstract}

KEYWORDS: Acipenser gueldenstaedtii, innate defenses, temperature, immunostimulator

\footnotetext{
* These authors have contributed equally to this work.

$\S$ Corresponding author. Tel.: +598 24874320.

E-mail address: aferrei@fq.edu.uy
} 